\title{
MATTHEW'S PORTRAIT OF JESUS THE JUDGE With SPECIAL REFERENCE TO MATTHEW 21-25'
}

\begin{abstract}
Alistair I. Wilson
The argument of this thesis is that a study of Jesus as Judge, as presented in chapters 21-25 of the gospel of Matthew, leads to conclusions which are incompatible with either the image of the apocalyptic prophet of imminent catastrophe (as proposed by J. Weiss and A. Schweitzer) or the 'non-eschatological Jesus' of M. Borg. Rather, Matthew's Jesus makes authoritative declarations of judgement on his contemporaries, drawing deeply from the Jewish Wisdom and prophetic traditions in both form and content, yet does so with an eschatological perspective which perceives ultimate judgement to lie in a climactic event at an undefined point in the future in which he will play a dominant role. This image of Jesus as he appeared to Matthew must be seriously taken into account in attempts to rediscover the 'historical Jesus'.

The 'apocalyptic prophet' understanding of Jesus has dominated research on Jesus in the last hundred years, and while there are some valid insights in this portrait, it has normally led to an assumption that Jesus expected the final judgement to come upon the world imminently, or within a generation at the latest. This has led to a neglect of Jesus' role as a judge on his contemporary society. In response to this dominant portrait of Jesus, several contemporary scholars have advocated a 'non-apocalyptic' Jesus, who stands in the tradition of the wise teacher. Some trace this strand back to GraecoRoman origins, while others see a more Jewish background. In either case, there is little interest in the concept of Jesus as a judge. Furthermore, many such studies draw indiscriminately and selectively from the synoptic gospels with the result that no one gospel is allowed to present its contribution to the discussion intact. At the same time, studies of the text of the gospels in their final forms tend to be purely
\end{abstract}

1 Ph.D. thesis, University of Aberdeen, 2001. Supervisor: Prof. I.H. Marshall. 
literary and raise the issue of the historical foundation which may be reflected in them.

In contrast to such trends in scholarship, this thesis sets out to examine a section of the canonical text of the gospel of Matthew (Matthew 21-25) with a view to assessing its contribution to the search for knowledge of Jesus as an historical figure. Methodologically, then, this thesis respects the literary coherence of the final form of the gospel of Matthew, but raises the question of its significance for an understanding of the historical Jesus.

Chapter 1 is a survey of some significant twentieth century literature in two categories. Firstly, studies of Jesus' view of judgement are discussed. These studies are further classified according to two main views of Jesus' teaching on judgement. Some scholars such as Kümmel, Barrett, and Hiers follow broadly the position of Schweitzer that Jesus anticipated eschatological judgement imminently. Others, such as Dodd, Glasson, Robinson and Borg claim that Jesus did not proclaim future eschatological judgement. Rather, he declared imminent judgement upon his contemporaries in language which has been misinterpreted in terms of a final cataclysm. Secondly, several studies which focus on the text of Matthew are discussed. These include early redaction-critical works such as that of Bornkamm and more recent studies which employ either redaction criticism (such as the major volume by Marguerat) or 'composition criticism' (such as B. Charette's published thesis) or sociological methodology (such as the work of D. Sim). The chapter concludes by arguing for the need to relate studies of an individual gospel, which allow the voice of the gospel narrative to be heard, to studies of the 'Historical Jesus'.

Chapter 2 argues for a methodological approach which enables the reader to treat Matthew's narrative as a coherent whole (employing 'composition criticism', understood as a form of redaction criticism which pays particular attention to the features of the text's final form), to take a confident approach to the gospel materials as reliable tradition and to relate Matthean studies to Historical Jesus studies on the grounds that every author, whether Matthew or Meier, produces a 'portrait' of Jesus. That is, in every case he or she selects material and presents it with a particular personal agenda so as to produce an end product which reflects the reality of the person of Jesus. Each portrait may, of course, be evaluated with respect to how well it reflects reality, but no modern 'portrait' can be given a methodological priority over another ancient 'portrait'. 
Chapter 3 argues that chapters 21-25 of Matthew's gospel display literary coherence in presenting Jesus as judge, not primarily in terms of judgement vocabulary (which is relatively scarce) but in terms of judgement sayings which do not directly employ 'judgement language' and also of acts of judgement. It also confirms that the theme of judgement is characteristic of Matthew's gospel, by means of a brief survey of the whole gospel and thus indicates that the theme is of central significance to the author of the gospel. The chapter does, however, also recognise that the theme of judgement is by no means confined to these chapters and gives some consideration to relevant material from other parts of the gospel.

Chapters 4 and 5 take up the use of the models of 'prophet' and 'sage' respectively (following, in part, M. Borg), and investigate the theme of judgement in selected portions of the canonical and noncanonical Jewish literature associated with the prophets and the sages. It emerges that Jesus' proclamation of judgement reflects themes found in both prophetic and Wisdom literature. Chapter 4 argues that Matthew regards 'prophet' as an appropriate (if not exhaustive) description of Jesus and so his narrative may be read with particular sensitivity to resonance with the OT prophets and prophetic literature. Of particular significance are the several accounts of 'prophetic acts' in chapter 21; the use of prophetic forms of speech in chapter 23 and the presentation of Jesus as prophet of forthcoming judgement in chapters 24-25. Of particular significance in the ongoing discussion over Jesus' eschatological expectations, which are clearly of great significance for his teaching and actions relating to judgement, is the nature of 'apocalyptic' language. This thesis therefore discusses the biblical language at the centre of the debate in the light of its location in Matthew's text and considering the most likely background to his thinking. I conclude that many scholars have driven too great a wedge between what is 'apocalyptic' and what is 'prophetic', and propose that 'apocalyptic' texts in Matthew are best interpreted with the canonical prophetic literature as the most significant backdrop. We submit that when this material is read in its canonical context, its significance becomes clear so that it is no longer necessary to regard it as predictive of the parousia but rather symbolic of a great vindication of Jesus. In particular, when these sayings are interpreted in their context in Matthew's gospel, according to the approach to 'apocalyptic' language argued for in the thesis, they may be understood as natural and appropriate sayings of Jesus. That is, by means of recognising their coherence with the narrative in which they 
are set when interpreted in a manner in keeping with their most likely literary background, these sayings may be said to have a substantial claim to being authentic portions of the teaching of the historical Jesus. Chapter 5 surveys selected passages from canonical and noncanonical Wisdom literature where reference is made to judgement. There then follows a discussion of Jesus' use of meshalim, both in general and in Matthew 21-25. The chapter concludes that Matthew presents Jesus as a teacher of wisdom, drawing on the form, techniques and sometimes the themes of Wisdom literature in order to communicate a declaration of judgement on those who rejected him as God's chosen one and who oppressed others. Thus, Matthew portrays Jesus as prophet by means of his accounts of Jesus' prophetic acts, his declaration of impending national catastrophe and his warning of eschatological judgement. Equally, he portrays Jesus as sage by means of his emphasis on the provocative aphoristic and narrative meshalim which Jesus employs to expose the errors of the Jewish religious leaders and to declare judgement upon them. He also highlights Jesus' emphasis, typical of Wisdom literature, on the judgement of God upon injustice, while not hesitating to indicate the eschatological element in Jesus' Wisdom sayings.

Chapter 6 of the thesis concludes that Matthew presents Jesus as one who embodies the prophet and the teacher of Wisdom, and who goes beyond these figures in important ways as he takes to himself the role of judgement in a way that is highly distinctive among the religious figures of his day. 